\title{
Prediction of products yield at the thermal cracking of vegetable oil
}

\author{
Doinita Roxana CIOROIU and Claudia Irina KONCSAG*
}

Department of Chemistry and Chemical Engineering, „Ovidius” University of Constanta, 124 Mamaia Blvd., Constanta 900527, Romania

\begin{abstract}
According to previous studies on the pyrolysis of vegetable oils, it resulted that the thermal cracking process is prone to produce large yields of ethylene, propylene, hydrogen and methane, comparable with the gas proceeding from the steam cracking of naphtha, but at much lower process temperature, this ensuring important energy savings. The studies are performed on very different raw materials and different reaction conditions, that being why at this moment it is very difficult to predict the products yield. This paper uses an analytical semiempirical model (ASEM) developed at the University of Florida, by applying it to a different raw material. The ASEM model fits very well to our experimental data, obtained at higher temperature but some parameters have to be adjusted. In the end we confirm a set of systemic parameters to be used for the prediction of main products yield proceeding from vegetable oil in an extended range of temperatures.
\end{abstract}

Keywords: waste vegetable oil, cracking, olefins, systematics, ASEM

\section{Introduction}

Vegetable oils are renewable resources for fuels production and petrochemicals due to their chemical composition have some similarities with the crude oil, both containing long chains of hydrocarbon. Despite the good olefin yields $[1,2,3]$, the pyrolysis of vegetable oil is still not an industrial option, the main reason for this being the desire to preserve the food resources. However, there are opportunities such as non-food vegetable oils in large quantities (Copaiba, Jatropha oil, Jojobe oil) and waste cooking oil.

Experimental studies were carried out with canola [1,2], soybean [3], palm [1] sunflower oils [4], and also with fractions of C4-C18 saturated triglycerols and C18 unsaturated tryglycerols [1]. All demonstrated that the yields of olefins, aromatics and other valuable compounds are similar to that obtained in petroleum fractions steam cracking.

For the industrial scaling up, it is compulsory to know with accuracy the products yield. Every experimental study contained correlations of product yields with the temperature and raw origin. A very useful analytical semi-empirical method (ASEM) was developed at the University of Florida [2] in order to predict product yields.

In this work, we compare experimental results obtained at the thermal cracking of different oils [1, 4] with those predicted with the ASEM method [2], in order to conclude if the method can be applied with confidence.

\section{The analytical semi-empirical model ASEM}

The model was proposed by the Clean Combustion Technology Laboratory (CCTL) in Atlanta [2], after processing experimental data obtained in their laboratory [5-8].

It consists in three equations (Eq.1-3) for the prediction of products yields:

$$
y(t)=w\left[L\left(T: T_{0}, D\right)\right]^{p}\left[F\left(T: T_{0}, D\right)\right]^{q}
$$

where:

$$
L\left(T: T_{o}, D\right)=\frac{\exp \left[\left(T-T_{0}\right)\right]}{1+\exp \left[\left(T-T_{o}\right) / D\right]}
$$


82 Prediction of products yield at the thermal... / Ovidius University Annals of Chemistry 25 (2), 81-84 (2014)

and:

$$
F\left(T: T_{0}, D\right)=1-L\left(T: T_{0}\right) / D
$$

The significance of the symbols in Eqs (1-3) is listed below:

D- parameter of logistic (Eq.1)

$\mathrm{F}(\mathrm{T})$-forgetting function (Eq.3)

$\mathrm{L}(\mathrm{T})$ learning function (Eq.2)

p,q- constants (Eq.1)

$\mathrm{t}$ - residence time

$\mathrm{T}$ - cracking temperature $[\mathrm{K}]$

$\mathrm{T}_{0}$ - critical cracking temperature $[\mathrm{K}]$

w- parameter of logistic function(Eq.1)

$\mathrm{y}_{\mathrm{i}}=$ individual yield $(\% \mathrm{wt})$

$\mathrm{Y}=$ total yield $(\% \mathrm{wt})$

The five parameters involved in equations 1-3 are $\mathrm{T}_{0}, \mathrm{D}, \mathrm{w}, \mathrm{p}$ and $\mathrm{q}$. For the canola oil thermocracking, $\mathrm{T}_{0}=648 \mathrm{~K}$ and $\mathrm{D}=313 \mathrm{~K}$ and $\mathrm{w}, \mathrm{p}$ and $\mathrm{q}$ are specific for each individual product, as seen in Table 1[2]:

Table 1. Parameters of ASEM equations for canola oil thermocracking [2]

\begin{tabular}{|c|c|c|c|c|}
\hline \multicolumn{5}{|l|}{ Olefins } \\
\hline Parameter & $\mathrm{C}_{2} \mathrm{H}_{4}$ & $\mathrm{C}_{3} \mathrm{H}_{6}$ & $\mathrm{i}-\mathrm{C}_{4}{ }^{\prime}$ & $1-\mathrm{C}_{4}{ }^{\prime}$ \\
\hline $\mathrm{w}$ & 25.0 & 15.5 & 1.2 & 0.8 \\
\hline $\mathrm{p}$ & 1.0 & 1.0 & 0.9 & 1.5 \\
\hline$q$ & 0 & 0.03 & 0.04 & 0.04 \\
\hline \multicolumn{5}{|l|}{ Paraffins } \\
\hline Parameter & $\mathrm{CH}_{4}$ & $\mathrm{C}_{2} \mathrm{H}_{6}$ & $\mathrm{C}_{3} \mathrm{H}_{8}$ & $\mathrm{C}_{4} \mathrm{H}_{10}$ \\
\hline W & 11.6 & 8 & 1.33 & 8.1 \\
\hline $\mathrm{p}$ & 1.0 & 0.8 & 0.6 & 0.9 \\
\hline$q$ & 0.01 & 0.02 & 0.03 & 0.04 \\
\hline \multicolumn{5}{|c|}{ Oxygenates } \\
\hline Parameter & $\begin{array}{l}\mathrm{CH}_{4} \mathrm{O} \\
\text { (methanol) }\end{array}$ & & & \\
\hline $\mathrm{W}$ & 3.7 & & & \\
\hline $\mathrm{p}$ & 0.3 & & & \\
\hline$q$ & 0.7 & & & \\
\hline \multicolumn{5}{|l|}{ Others } \\
\hline Parameter & $\mathrm{H}_{2}$ & $\mathrm{CO}$ & $\mathrm{CO}_{2}$ & Coke \\
\hline $\mathrm{w}$ & 1.3 & 3 & 1.5 & 4.2 \\
\hline $\mathrm{p}$ & 1.4 & 2 & 0.2 & 2 \\
\hline$q$ & -0.1 & -0.1 & 0.2 & -0.1 \\
\hline
\end{tabular}

\section{Experimental data}

We used our experimental data obtained at the steam cracking of waste frying vegetable oil in a micropilot plant, at atmospheric pressure, $650^{\circ} \mathrm{C}$ and steam-to-feed ratio 1:1 wt. The yields of different compounds were determined by material balance combined with composition of pyrolysis gas determined by up-to-date chromatographic analysis method Refinery Gas Analysis developed by Wasson on Agilent $6890 \mathrm{~N}$ with multiple columns and different detectors. The experiment is described in [4].

These data are presented in Table 2 and were compared with data in literature obtained in other thermocracking experiments, at atmospheric pressure in presence of an inert gas (nitrogen or steam).

Table 2. Comparative experimental data for yields (\% wt) of products in pyrolysis gas obtained at the thermal cracking of vegetable oils

\begin{tabular}{|c|c|c|c|}
\hline $\begin{array}{l}\text { Chemical } \\
\text { compound }\end{array}$ & $\begin{array}{l}\text { Yield, } \\
\% \mathrm{wt} \\
\text { in this } \\
\text { experiment }\end{array}$ & $\begin{array}{c}\text { Yield, } \\
\% \text { wt in } \\
\text { Zamostny } \\
\text { et al. } \text { [1] } \\
\text { experiment }\end{array}$ & $\begin{array}{c}\text { Yield, } \\
\% \text { wt in } \\
\text { Sadrameli } \\
\text { \&Green [2] } \\
\text { experiment }\end{array}$ \\
\hline $\mathrm{CH}_{4}$ & 11.2 & $\begin{array}{l}\text { Data not } \\
\text { found }\end{array}$ & 10.6 \\
\hline $\mathrm{C}_{2} \mathrm{H}_{6}$ & 5.7 & $\begin{array}{l}\text { Data not } \\
\text { found }\end{array}$ & 7.0 \\
\hline $\mathrm{C}_{2} \mathrm{H}_{4}$ & 19.8 & 28.0 & 23.7 \\
\hline $\mathrm{C}_{3} \mathrm{H}_{8}$ & 0.8 & $\begin{array}{l}\text { Data not } \\
\text { found }\end{array}$ & 1.15 \\
\hline $\mathrm{C}_{3} \mathrm{H}_{6}$ & 6.1 & 10.5 & 13.6 \\
\hline $\mathrm{H}_{2}$ & 4.4 & $\begin{array}{l}\text { Data not } \\
\text { found }\end{array}$ & 1.66 \\
\hline $\mathrm{CO}_{2}$ & 4.3 & 15.8 & 3.87 \\
\hline $\mathrm{i}-\mathrm{C}_{4} \mathrm{H}_{8}$ & 0.1 & $\begin{array}{l}\text { Data not } \\
\text { found }\end{array}$ & 1 \\
\hline $\begin{array}{c}\text { Linear } \\
\mathrm{C}_{4} \mathrm{H}_{8}\end{array}$ & 1.5 & $\begin{array}{l}\text { Data not } \\
\text { found }\end{array}$ & 2.0 \\
\hline $\mathrm{C}_{4} \mathrm{H}_{10}$ & 1.9 & $\begin{array}{l}\text { Data not } \\
\text { found }\end{array}$ & 6.67 \\
\hline
\end{tabular}

Experimental data presented in Table 2 were obtained in similar experiments: continuous processes of thermal cracking, with inert gas carrier, 
to prevent carbonaceous deposits. All refers to generic "vegetable oils" since products yields were comparable between different vegetable oils and even between vegetables oils and fossil gas oil [2].

These experimental data were obtained in very different temperature conditions: $650{ }^{\circ} \mathrm{C}$ in our experiment [4], $820^{\circ} \mathrm{C}$ in [1] and $500^{\circ} \mathrm{C}$ in [2]. Also, the carrier gas was different: steam in our experiment and nitrogen in [1,2].

\section{Results and discussions}

In Table 2, one can see similarities and differences:

$-\mathrm{C}_{4}$ hydrocarbon yields in pyrolysis gas are similar but this is not relevant since it depends not only on the pyrolysis process but also on the cooling agent temperature determining how much $\mathrm{C}_{4}$ remains in the liquid phase and how much is recovered in gas; $-\mathrm{CH}_{4}$ yield shows a clear tendency to increase with the temperature rise;

- $\mathrm{C}_{2} \mathrm{H}_{4}$ yield increases with temperature rise

- $\mathrm{C}_{3} \mathrm{H}_{6}$ and $\mathrm{C}_{3} \mathrm{H}_{8}$ yields should also increase with temperature rise but results are not conclusive.

Next step was the processing of our experimental data with the semiempirical model ASEM, using the parameters recommended in [2]. Results are shown in Table 3:

Using the ASEM model, some of data fitted to its parameters: ethane, ethylene, hydrogen, propane and $\mathrm{C}_{4}$ unsaturated hydrocarbons yields. For others, like methane, propylene, $\mathrm{CO}_{2}$ and butane yields, the errors are important. For these, adjustment of parameters in Equations 1-3 should be done.
Table 3. Results of applying the parameters of ASEM model to experimental data

\begin{tabular}{|c|c|c|}
\hline $\begin{array}{c}\text { Chemical } \\
\text { compound }\end{array}$ & $\begin{array}{c}\text { Experimental } \\
\text { yields, \% wt }\end{array}$ & $\begin{array}{c}\text { Calculated } \\
\text { yields with } \\
\text { ASEM model }\end{array}$ \\
\hline $\mathrm{CH}_{4}$ & 11.2 & 8.1 \\
\hline $\mathrm{C}_{2} \mathrm{H}_{6}$ & 5.7 & 5.9 \\
\hline $\mathrm{C}_{2} \mathrm{H}_{4}$ & 19.8 & 18.5 \\
\hline $\mathrm{C}_{3} \mathrm{H}_{8}$ & 0.8 & 1.0 \\
\hline $\mathrm{C}_{3} \mathrm{H}_{6}$ & 6.1 & 10.6 \\
\hline $\mathrm{H}_{2}$ & 4.4 & 4.3 \\
\hline $\mathrm{CO}_{2}$ & 4.3 & 1.1 \\
\hline $\mathrm{i}-\mathrm{C}_{4} \mathrm{H}_{8}$ & 0.1 & 0.1 \\
\hline Linear $\mathrm{C}_{4} \mathrm{H}_{8}$ & 1.5 & 1.7 \\
\hline $\mathrm{C}_{4} \mathrm{H}_{10}$ & 1.9 & 5.6 \\
\hline
\end{tabular}

Changing only the parameter $w$ in equation 1, one can obtain better results for methane, propylene, and $\mathrm{CO}_{2}$ yields. For methane, new $w=16.04$ instead of 11.6, for propylene let's keep $w=15.5$, for $\mathrm{CO}_{2}: w=4.9$ instead of 1.5. For butane, it is no point to adjust the parameters, since it is shared between the liquid and the vapour phase and the share depends on the cooling agent temperature.

In order to validate these new values for $w$, they will be applied together with the other parameters $p$ and $q$ (see Table 1) in Equations 1-3, in order to calculate the yields of these three components and to compare them with the experimental data at $400^{\circ} \mathrm{C}, \quad 450^{\circ} \mathrm{C}, \quad 500^{\circ} \mathrm{C}$ presented in [2]. Also, we present comparatively our experimental results with those calculated with new parameters, in the Table 4.

Table 4. Comparison of experimental yields in [2] and [4] with those calculated with adjusted w parameter in Eq.1

\begin{tabular}{|c|c|c|c|c|c|c|c|c|c|c|c|c|}
\hline \multirow[t]{2}{*}{ Product } & \multicolumn{3}{|c|}{$\begin{array}{l}\text { Yield, \% wt } \\
\text { Ref [2] }\left(\mathrm{t}=400^{\circ} \mathrm{C}\right)\end{array}$} & \multicolumn{3}{|c|}{$\begin{array}{l}\text { Yield, \% wt } \\
\text { Ref [2] }\left(\mathrm{t}=450^{\circ} \mathrm{C}\right)\end{array}$} & \multicolumn{3}{|c|}{$\begin{array}{l}\text { Yield, \% wt } \\
\text { Ref [2] }\left(\mathrm{t}=500^{\circ} \mathrm{C}\right)\end{array}$} & \multicolumn{3}{|c|}{$\begin{array}{l}\text { Yield, \% wt } \\
\text { Ref [4] }\left(\mathrm{t}=650^{\circ} \mathrm{C}\right)\end{array}$} \\
\hline & Exp. & Calc. & $\begin{array}{l}\text { Error } \\
\%\end{array}$ & Exp. & Calc. & $\begin{array}{l}\text { Error } \\
\%\end{array}$ & Exp. & Calc. & $\begin{array}{l}\text { Error } \\
\%\end{array}$ & Exp. & Calc. & $\begin{array}{l}\text { Error } \\
\%\end{array}$ \\
\hline $\mathrm{CH}_{4}$ & 7.1 & 8.28 & -16.6 & 9.95 & 8.91 & +10.5 & 10.6 & 9.54 & +10.0 & 11.2 & 11.3 & -1.3 \\
\hline $\mathrm{C}_{3} \mathrm{H}_{6}$ & 10.3 & 7.7 & +25.2 & 12.25 & 8.5 & +30.6 & 13.6 & 9.1 & +33.1 & 6.1 & 10.6 & -73.8 \\
\hline $\mathrm{CO}_{2}$ & 2.9 & 3.7 & -27.6 & 3.75 & 3.70 & +1.3 & 3.87 & 3.8 & +1.8 & 4.3 & 3.6 & +16.3 \\
\hline
\end{tabular}


84 Prediction of products yield at the thermal... / Ovidius University Annals of Chemistry 25 (2), 81-84 (2014)

As seen in Table 4, an adjustment of parameter $w$ for $\mathrm{CH}_{4}$ and for $\mathrm{CO}_{2}$ can be made with satisfactory results at least in the range of $450^{\circ} \mathrm{C}$ $650^{\circ} \mathrm{C}$. As for $\mathrm{C}_{3} \mathrm{H}_{6}$ the results are unsatisfactory even for the parameters applied on the experimental data being the source of the ASEM model. The parameters can be adjusted as follows:

$$
\begin{array}{ll}
\text { - } & w=15.5 \\
\text { - } & p=0.5 \\
\text { - } & q=0.03
\end{array}
$$

This will fit very well to the data in the original study [2] with relative errors between 4.9$5.7 \%$, but our results at $650^{\circ} \mathrm{C}$ are far from being described with accuracy by this model, and this is the same at $820^{\circ} \mathrm{C}[1]$. This can be explained by consecutive reactions suffered by the propylene in the reactor at $650^{\circ} \mathrm{C}$ in presence of water, most probably the decomposition.

\section{Conclusions}

The analytical semi-empirical model (ASEM) for the prediction of products yield at the thermal cracking of vegetable oil was originally worked out for canola oil in the temperature range $300-500^{\circ} \mathrm{C}$. This range can be extended to $650^{\circ} \mathrm{C}$ for vegetable oil in general, with confidence, except for propylene yield. The model's parameters need small adjustments for methane and carbon dioxide.

In general, the original parameters of the ASEM method can be preserved with small adjustment for methane and carbon dioxide. A different set of systemic parameters for propylene yield prediction can be applied in a narrow range $\left(400-500^{\circ} \mathrm{C}\right)$ which is the usual temperature range.
This model can be improved by processing other experimental data when available.

\section{References}

*E-mail address: ckoncsag@univ-ovidius.ro

[1] P.Zamostny, Z.Belohlav and J. Smidrkal Resources, Conservation and Recycling, 59, 47-51 (2012).

[2] S.M. Sadrameli and A.E.S. Green, J. Anal. Appl. Pyrolysis, 78, 445-451 (2007).

[3] A.Kubatova, Y.Luo, J.Štavova, S.M.Sadrameli, T.Aulich, E.Kozliak and W. Seames, Fuel, 90 (8), 2598-2608 (2011).

[4] CI,Koncsag, A.E.Sterpu, A.I. Dumitru and T Chis, Proceedings 14 th GeoConference on Energy and Clean Technology, SGEM 2014, vol.II, 183190 (2014).

[5] A. Green, P. Venkatachalam and M.S. Sankar Feedstock Blending of domestic Fuels in Gasifier/Liquifiers, TURBO EXPO, Amsterdam, GT, 1-10. (2002).

[6] A. Green and R. Chaube, Pyrolysis Systematics for Co-Utilization Applications, TURBO EXPO, Atlanta, GA, GT, pp. 1-10. (2003).

[7] A.R. Green and A. Chaube, Int. J. Power Energy Syst. 24, 215-223 (2004).

[8] A. Green and S.M. Sadrameli, JAAP 72 (2) 329-335 (2004).

Submitted: November $4^{\text {th }} 2014$ Accepted in revised form: November $16^{\text {th }} 2014$ 